\title{
ЛИТЕРАТУРОВЕДЕНИЕ
}

\author{
UDC 821.113.6
}

Anna Bohlin

Stockholms universitet

\section{FREDERIKA BREMER: PROTESTANTISK PILGRIM I PALESTINA ÅR 1859}

Pilgrimage Studies is a growing field of research; however, Protestant pilgrims in the $19^{\text {th }}$ century have so far received little attention. Fredrika Bremer (1801-1865), world-famous Swedish author at the time, published an account of her five months in the Holy Land in 1859, in the travel book Life in the Old World (1860-1862), covering Switzerland, Italy, Turkey and Greece apart from Palestine. Throughout the narrative of the Biblical lands, Bremer discusses the significance of pilgrimage in relation to pilgrims of other Christian denominations. As a Protestant, she needs to ask herself in what way the physical place, the materiality of the holy sites, carries a meaning. In applying Charles Lock's concept "the Protestant optic", the analysis shows that Bremer concur with British and American Protestant pilgrims of her time in preferring landscapes to monuments and in complaining about the emotional expressions of devotion by Catholic and Orthodox pilgrims. Nevertheless, she also diverges from their standing on devotional practices. Her own critical method of making sense of holy sites results in what I call "allegorical geography": she understands the inner meaning of the Gospel to be inscribed into the topography. Ultimately, in Bremer's travel account, the pilgrimage is motivated, I suggest, by the aesthetic impression of the landscape, the sensuous perception that gives evidence to the truth of the Bible.

Keywords: Frederika Bremer, Pilgrimage Studies, nineteenth century Protestant pilgrims, travel narrative, Palestine, topography.

\section{Анна Болин \\ Стокгольмский университет \\ ФРЕДЕРИКА БРЕМЕР: ПРОТЕСТАНТКА И ПАЛОМНИЧЕСТВО В ПАЛЕСТИНУ В 1859 ГОДУ}

Изучение паломничества - перспективная область научных исследований, однако до сих пор в литературе уделяется довольно мало внимания паломникампротестантам XIX века. Фредерика Бремер (1801-1865), известная на тот момент во всем мире шведская писательница, в 1859 году опубликовала заметки о пятимесячном пребывании на Святой земле в книге путевой прозы «Жизнь в Старом Свете» (1860-1862), рассказывающей помимо Палестины о путешествиях писа- 
тельницы по Швейцарии, Италии, Турции и Греции. Весь нарратив, в котором Бремер рассказывает о библейских местах, посвящен важности паломничества для пилигримов других ветвей христианства. Будучи протестанткой, она задается вопросом о том, каким же смыслом обладают физическое местоположение, материальная реальность священных мест. Амплифицируя концепцию «протестантской оптики» Чарльза Локка, анализ показывает, что Бремер, вслед за британскими и американскими протестантами той эпохи, предпочитает природу архитектурным памятникам, а также жалуется на силу эмоциональной экспрессии католических и православных паломников, выражающих таким образом свою преданность вере. Однако ее мнение о практиках преданности отличается от мнения других протестантов. Ее собственный критический метод понимания священных мест сводится к тому, что я называю «аллегорической географией»: она понимает скрытый смысл Слова Божьего, проявляющийся в топографии этой местности. В целом путевые заметки Бремер, по нашему мнению, дают понять, что основным мотивом паломничества являются эстетические впечатления от ландшафта, чувственное восприятие, благодаря которому мы получаем подтверждение библейских истин.

Ключевые слова: Фредрика Бремер, исследования паломничества, протестантские пилигримы XIX века, художественный нарратив путевой прозы, Палестина, топография.

Fredrika Bremer (1801-1865) räknade inte med att bli pilgrim. ${ }^{1}$ När den världsberömda författaren lämnade Sverige på försommaren 1856 var planen att vistas i Schweiz några månader för att studera den schweiziska frikyrkan. I själva verket kom resan att vara i fem år och omfatta Italien, Turkiet, Grekland - och Palestina. I reseberättelsen Lifvet $i$ gamla verlden. Dagboks-anteckningar under resor i Söder-och Österland (1860-1862) påstår Bremer att hon inte ens vet varför hon reser till det Heliga Landet: "Ett blott vet jag och det är — att jag måste dit." [Bremer, 1861. II:I, s. 58] Bremer var djupt troende kristen. Hon menade att den världshistoriska utvecklingen hängde på kvinnors samhällsdeltagande, och att både samhällsutveckling och kvinnoemancipation var inbegripna i Guds plan med mänskligheten. Men varför måste hon uppsöka det fysiska landskap där Bibelns berättelser utspelade sig? Och hur skapade platsen mening för pilgrimen? Det är en diskussion som Bremer själv för genom hela skildringen av det fem månader långa besöket i Palestina år 1859.

${ }^{1}$ En längre version av denna artikel år publicerad under rubriken under rubriken "Att kyssa olivträd. Fredrika Bremer som ambivalent pilgrim till det Heliga Landet" i antologin Fiktion och verklighet. Mångvetenskapliga möten, red. Anna Bohlin \& Lena Gemzöe. Göteborg \& Stockholm: Makadam förlag, 2016. 
Bremer kom att möta det Heliga Landet i sällskap med den ryska furstinnan Sachatsjkova och professor Basilius Lewison från St. Petersburg, ursprungligen en tysk rabbin som konverterat till kristendomen. ${ }^{2}$ Bekantskapen inleddes på ångbåten Borysthène, där furstinnan erbjöd Bremer att resa den farliga vägen från Jaffa till Jerusalem i hennes sällskap, "i skydd af den eskort, som ryska authoriteterna skulle förskaffa henne" [Bremer, II:I, s.68]. Lättad tackade Bremer ja, och fick därigenom övernatta i det grekiska klostret i Ramleh. Det Heliga Landet gav inte bara närkontakt med Bibelns berättelser, utan också med kristna bekännare av olika inriktning. Under 1800-talet utgjorde protestantiska pilgrimer en växande grupp, som profilerade sig mot andra kristna. Vitt skilda sätt att uttrycka vördnad för heliga platser var en aldrig sinande källa till konflikt i protestantiska pilgrimsberättelser och Bremers är inget undantag. Furstinnan beskrivs med beundran och respekt, men Bremer har ingen förståelse för att hon vakar i den Heliga gravens kyrka. Innan jag utvecklar Bremers diskussion om platsens innebörd finns emellertid anledning att ägna uppmärksamhet åt genren.

\section{Reseskildring/pilgrimsberättelse}

Reseberättelsen som genre hade under 1800-talet vetenskapliga anspråk som är främmande för vår tids reseberättelser. Den kunskap som samlades i reseskildringar kom senare att inordnas i discipliner som sociologi, naturhistoria, etnologi och antropologi [Harper, 2001; Pratt 1992; Thompson, 2011]. Det märkvärdiga med Bremers företag var att som ensam kvinna ge sig iväg så långt bort, så länge och att dessutom publicera en reseskildring, men hon var inte unik: skaran av kvinnliga reseberättare var förvisso inte stor, men tilltagande. Genren erbjöd möjligheten att etablera en vetenskaplig auktoritet i offentligheten trots att kvinnor förbjöds tillträde till högre utbildning. ${ }^{3}$ Den vetenskapligt iakttagande kvinnliga resenären var en provocerande nyhet, men den kvinnliga pilgrimen var tvärtom en gestalt med långa anor i den västerländska kulturhistorien. En av de tidigaste pilgrimsberättelserna var faktiskt skriven av en kvinna, Egeria, som reste från Gallien (nuvarande

2 Ang. furstinnans namn, som i reseskildringen ändrats till Shahovskoy, se Carina och Lars Burman, 1995. S. 406.

${ }^{3}$ Harper, 2001. S.16ff. För en mer utförlig diskussion av genren och Bremers reseskildring från Amerika se Bohlin, 2013. 
Spanien) till det Heliga Landet redan på 380-talet [Thompson, 2011, p. 36f.].

Det har aldrig funnits någon enhällig uppslutning bakom tanken om pilgrimsfärdens välgörande verkan. Tvärtom mötte pilgrimsfärderna inledningsvis starkt motstånd, inte minst från kyrkofäderna, som i stället hävdade den inre resan: Gud ska sökas i hjärtat (även om ett par av dem ändå vallfärdade till Jerusalem). Gud fanns överallt och var, som bland andra Augustinus betonade, inte begränsad till Palestina [Edwards, 2005; Coleman \& Elsner, 1995; Bowman, 1991]. Konflikten skärptes med 1500-talets protestantiska rörelser som med kraft vände sig mot den fysiska pilgrimsresan. Den svenska riksdagen gick så långt att man år 1544 förbjöd pilgrimsfärder [Gunner, 1999, s. 273] och den omåttligt populära The Pilgrim's Progress (1678-1684) av John Bunyan är del av en rik litteratur, där pilgrimsmotivet uteslutande förstås i metaforisk mening [Edwards, 2005, s.187-195]. Philip Edwards konstaterar att en stark och långlivad tradition gör gällande att den sanna pilgrimen inte är den verkliga pilgrimen. ${ }^{4}$ Pilgrimsresans huvudbetydelse var länge den inre resan, den kristnes färd genom livet mot himlen, vilket har att göra med hur ordet "pilgrim" användes i den latinska översättningen av Bibeln [Edwards, 2005, s. 8f]. Peregrinus är det latinska ordet för "främling", "en resande från ett annat land". Hebreerbrevet (11:13-16) knyter an till den längtan till det förlovade landet som genomsyrar Gamla Testamentet, men exilen används som en bild för den kristnes alienation i en syndig värld på väg till sitt hemland i himlen. ${ }^{5}$

Kvinnor har begivit sig på pilgrimsfärder i alla tider, men de har ofta misstänkliggjorts och deras vallfart har kringgärdats av genusspecifika förväntningar. Leigh Ann Craig, som studerat 1300- och 1400-talens

${ }^{4}$ Edwards, 2005. S. 12. Kristendomen är för övrigt inte ensam om föreställningen om den inre pilgrimsresan. Den förekommer även bland hindumystiker, och vissa sufiordnar värderar en inre vallfart högre än en yttre. Coleman \& Eade, 2004. S. 14; Coleman \& Elsner, 1995. S. 70ff.

${ }^{5}$ Edwards, 2005. S. 5ff. En annan passage där Vulgata använder peregrinus i samma överförda bemärkelse är Första Petrusbrevet (2:11). Ett par verser i evangelierna kom också att uppfattas som legitimering av pilgrimsresor, trots att Jesus aldrig uppmanade till vallfart. "Jag är vägen, sanningen och livet” (Joh. 14:5-6), säger Jesus och ger en bild av kristna på väg mot ett heligt mål. "Kom och följ mig", säger han i Matt. 4:19 och i Luk. 24:13-33 framträder den uppståndne Kristus själv som pilgrim när lärjungarna möter honom på vägen till Emmaus. Ibid., S. 7ff; Coleman \& Elsner, 1995, S. 80; Coleman \&Elsner, 2003; Moore, 2003. S. 64ff. 
kvinnliga pilgrimer, drar slutsatsen att även om samma regler formellt gällde för pilgrimer av båda könen, måste kvinnors pilgrimsresor kunna uppfattas som en utvidgning av omsorgsarbetet i hemmet för att undgå kritik. Helst skulle vallfärden gå till en närbelägen helgedom med syftet att be för någon sjuk familjemedlem. Längre pilgrimsresor till Rom och Jerusalem var betydligt svårare att motivera [Craig, 2009]. Curiositas, nyfikenhet på allt som var onödigt ur frälsningssynpunkt, var vallfärdens största fara [Williams, 2009]. Man kunde lätt misstänka att pilgrimer var uttråkade i sina hem snarare än oroade för sina själar. Särskilt kvinnors rörlighet ansågs inbjuda till allsköns laster från lust och girighet till högmod och falskhet, och den kvinnliga pilgrimen, begiven på osedlighet, var en populär figur i den medeltida floran av misogyna satirer [Craig, 2009]. Den hotande synden var vad vi idag kallar turism.

Vår tids pilgrimsresor går knappast att helt särskilja från turism ett förhållande som bland andra Ellen Badone och Sharon R. Roseman diskuterar under titeln Intersecting Journeys. ${ }^{6}$ Det är resultatet av en utveckling som startade redan på 1300-talet, när en högkonjunktur gav fler människor möjlighet att resa även till avlägsna pilgrimsorter som Jerusalem. Härmed förändrades genren pilgrimsberättelser: från att i första hand ha givit knapphändig praktisk information, mer eller mindre kopierad från tidigare skrifter i ämnet, rymde berättelserna allt fler individuella intryck och erfarenheter [Craig, 2009, s. 134ff; Williams, 2009, s. 205-239]. Denna utveckling var också för många högst ovälkommen och bekämpades med iver. Den sanna pilgrimen skulle ingå i vad Wes Williams kallar ett "kollektivt kontinuum": att läsa pilgrimsberättelser, företa den egna vallfärden och i sin tur berätta om den var att ikläda sig rollen som representant snarare än att bli en person [Williams, 2009, s.219]. Imitation var själva poängen och berättelserna speglar avvisandet av subjektivitet till och med i grammatiska pluralformer. Ambitionen att motverka pilgrimsfärdens affinitet till turism, att hålla isär den religiösa och den sekulära resan, förstärktes ytterligare under den katolska motreformationen [s. 216ff]. Vid det laget hade emellertid sekulärt resande fått sin egen litteratur.

Om reseberättelsen öppnade möjligheten för kvinnor att anta vetenskaplig auktoritet under 1800-talet, så hade pilgrimsväsendet under

${ }^{6}$ Badone \& Roseman, 2004. Ang. dagens förhållande mellan pilgrimsresa och turism se även t.ex. Coleman \& Eade, 2004, S. 9ff; Schramm, 2004; Margry, 2008. 
århundraden ändå erbjudit viss rörelsefrihet och rätt att tala. ${ }^{7}$ Som pilgrim till det Heliga Landet var Bremer del av en 1500 år gammal tradition av religiös kvinnlig auktoritet, men hon knyter an till denna katolska tradition genom att ta avstånd från den.

\section{Insockrad påve}

Bremer hävdade att katolicism var menligt för demokratin, ja, att katolicism och demokrati rentav var oförenliga. Fram till 1873 var det förvisso förbjudet för svenska medborgare att konvertera till katolicism och katolikskräcken var utbredd - Bremer intog egentligen en ovanligt tillåtande inställning. ${ }^{8}$ Hennes ekumenik var långt före sin tid; olika religioner hade enligt henne olika funktioner i den världshistoriska utvecklingen. Även om hon i slutändan såg framför sig en helt kristnad mänsklighet, behövdes fortfarande olika trossamfund för att ge människor med olika temperament utrymme att tillbe på det sätt som passar dem [Bohlin, 1966]. Teologen Sven-Erik Brodd sätter Lifvet i gamla verlden i relation till dåtida teologisk debatt och visar i en intressant analys av Bremers kyrkouppfattning hur hon utarbetar en dialektik mellan katolska respektive protestantiska kyrkor, som ska resultera i en syntes, "den 'högre' kyrkan" [Brodd, 2016, s. 199].

Som protestant uppfattade hon det katolska prästerskapets ställning och i synnerhet påvedömet som ett skadligt mellanled, som förvrängde relationen mellan individen och Gud. Under sin vistelse i Rom sökte hon och fick audiens hos påven, vars auktoritet hon undergrävt genom att meddela att hans yttre vittnade om ett gott kök, men knappast om djupare tankar. Slutsatsen efter audiensen fortsätter på mattemat: påven har "blifvit liksom insockrad och krystalliserad, så att hans inre, ursprungliga lif blifvit förqväfdt” [Bremer, 1860. I:II, s.203]. Detta sammanfattar väl Bremer kritiska analys av hela den katolska kyrkan.Vall-

${ }^{7}$ Craig understryker att även om ytterst få kvinnor skrev själva under medeltiden, hörs ändå deras röster eftersom det ingick i "kontraktet" med helgonen att de mirakel helgonet åstadkom skulle offentliggöras. Kanoniseringsprocesser krävde insamling av vittnesmål om under utförda av det presumtiva helgonet, varför några av dessa röster bevarats till eftervärlden. Craig, 2009. S. 107ff.

${ }^{8}$ Gustav III:s toleransedikt gav år 1781 katolska kyrkan laglig rätt att verka i Sverige, men den svenska medborgare som konverterade riskerade utvisning ur landet. Även efter 1873 inskränktes de medborgerliga rättigheterna för svenska konvertiter fram till 1951 års Lag om religionsfrihet. NE: romersk-katolska kyrkan. 
fart var det första ämne Bremer konfronterade när hon installerat sig i Rom. Botgörelse, skriver hon, är ett "heligt behof":

Om man syndat, om man svårt brutit emot någon gudomlig eller mensklig lag, om man vaknar under natten med aggande samvetsqval [... - huru godt, huru välsignadt att då veta något medel att utplåna eller försona!... Behofvet deraf har jagat menniskorna på piligrimsfärder [sic] till heliga orter (och gör det ännu i dag), behofvet deraf har låtit dem företaga de svåraste botöfningar. Det är ett heligt behof; det grundar sig på medvetandet om eviga heliga lagar. Man måste vörda detta på samma gång man måste fördömma den makt, som dristar aflösa synden och syndaren på grund af några yttre, usla penitensers utförande, stundom mera en lek, än ett straff. [Bremer, 1860. I:II, s. 128]

Pilgrimsresor ger inte avlösning från synd, slår Bremer fast och preciserar problemet: "Att dyrka den kroppsliga hylsan, som anden afkastat, det tillhör själar ännu i larf-tillstånd [...]." [I:II, s. 129] Men om den "kroppsliga hylsan" är så helt tömd på mening borde hon inte ha någon anledning att resa till Palestina.

Konflikten i hur den materiella verkligheten tillskrivs mening skärps också i det Heliga Landet och argumentet upprepas om och om igen: "Precist här eller der betyder föga för det andliga sinnet." [II:I, s. 108] Kristenhetens heligaste plats, den Heliga gravens kyrka i Jerusalem, kommenterar Bremer genom att citera Luther: "Den graf, i hvilken Herren legat och som turkarne innehafva, den frågar Gud lika mycket efter, som efter alla kor i Schweits." [II:I, s. 89] Samtidigt har platsen uppenbarligen betydelse, eftersom hon ständigt irriteras av allt som hon menar hindrar tillgången till platsens andliga liv — den insockrade påven är en figur som återkommer. I Nasaret anmärker hon spydigt på den ännu inte färdigbyggda kyrkan över Josefs hus: "Mycket osymboliskt och taktlöst [...] hafva katholikerna förvandlat Josephs föregifna timmermansverkstad till en liten budoir-lik kyrka, der altartaflan föreställer Joseph, lik en pariser-sprätt, hvilken låtsar vara timmerman." [II:II, s. 142] I Födelsekyrkans grotta i Betlehem har ortodoxa kristna hängt oljelampor vid krubban, men lämnat den grå klippan synlig i valvet. Bremer klagar: "Skada att menniskorna genom deras barnsliga glitter tillåta så litet att ses af denna betydningsfulla symbol [...]." [II:II, s. 87] I detta avseende är hon en typisk protestant. Just lamporna i Födelsekyrkan och hela den 
Heliga gravens kyrka var förargelseväckande stötestenar även för samtida protestantiska amerikaner [Queen, II, 1996].

Antropologen Glenn Bowman påminner om att protestanterna kom sent till Palestina, långt efter att andra kristna kyrkor byggt helgedomar över heliga platser. Medan katoliker uppfattar sin tillbedjan som del av en kyrka med en lång historia, representerad i kyrkobyggnaden, ser protestanter ofta kyrkobyggnaderna som monument över institutionens makt. Dagens protestantiska pilgrimer, skriver Bowman, föredrar istället att föreställa sig Kristus på platser där han vandrat; den inre bilden blir viktigare än den yttre platsen[Bowman, 1991, s.115ff]. Det gällde även Bremer och andra protestanter i hennes samtid.

\section{Protestantisk optik}

Att se är en historiskt och ideologiskt villkorad handling, skriver Charles Lock. Han myntar begreppet protestantisk optik för den särskilda blick varmed 1800-talets brittiska pilgrimer betraktade det Heliga Landet. Nyckelorden är distans och behärskning: Jerusalem beundras bäst på avstånd. Blicken söker utsikter med fri horisont; de utförliga beskrivningar av landskap i 1800-talets protestantiska pilgrimslitteratur är en konsekvens av att en inre bild av Jesus som medvandrare projiceras på omgivningen. Emellertid är det viktigt att upprätthålla skillnaden mellan att se och att känna. Helst ska man undvika att kyssande, närgångna pilgrimer av andra trosinriktningar kommer i vägen. Olivberget var protestanternas favoritmål, enligt Lock. ${ }^{9}$ Olivberget var också den plats Bremer älskade mest.

Bremer besökte ofta Olivberget, och strax innan hon lämnar staden, utropar hon: "O! detta berg! blott för att se det är det värdt att komma till Jerusalem." [Bremer, 1861. II:II, s. 106] Bremer omfattades av den protestantiska optik, som Lock beskriver, och kyssande grekisk-ortodoxa bekännare tar hon som bevis på "den ytlighet, i hvilken den grekiska kulten förfallit” [II:II, s. 89]. Brodd pekar på att den ortodoxa kyrkan inte får plats i den dialektik Bremer utarbetar. Utgångspunkten för

${ }^{9}$ Lock, 2003. Se även Ruth Hummel \& Thomas Hummel, 1995. I avskyn för kyssandet verkar 1800-talets brittiska pilgrimer följa en nationell tradition: Edwards citerar den anglikanska reformationens Latimer, som redan år 1538 uttryckte ett särskilt äckel inför traditionen att kyssa helgonbilder. Edwards, 2005, s. 28. Jfr också Williams, som lyfter fram en brittisk tradition av "negative national progress; a journey whose credit was defined in opposition to Popish superstition”. Williams, 2009, s.235. 
Bremers framställning är att kristenheten under 1800-talet började delas in i tre kyrkofamiljer: protestanter, romersk-katoliker och ortodoxa. Hon söker enligt Brodd "ecklesiologiskt användbara tolkningsnycklar för att förstå vad som är en ortodox kyrka” [Brodd, 2016, s. 209]. Han drar slutsatsen att hon uppfattar de tre kyrkofamiljerna som tre utvecklingsstadier, där ortodoxa kyrkan visserligen intar det lägsta stadiet, men att det också innebär en närmare kontakt med fornkyrkan. Det ger den ortodoxa kyrkan i Bremers tanke en särskild uppgift att föra det fornkyrkliga arvet in i framtidens kyrka, vid sidan av att utgöra en brygga mellan öst och väst [s. 211-217]. Bremer bryter också mönstret hos Locks brittiska resenärer genom att i den Heliga Gravens kyrka bli rörd av ortodoxa pilgrimers allvar och "synbara djupa andakt" [Bremer, 1861. II:I, s.91]. Hon går till och med så långt att hon ifrågasätter sin egen hållning:

Äro vi så visa i vår förståndiga protestantiska kyrka då vi derur hafva banlyst alla yttre tecken af tillbedjande kärlek, och stå styfva och stela, der de katholska och grekiska christna böja sina knän och närma varma, tillbedjande läppar? Jag tviflar derpå. Dock måste andens dragning vara fri och icke bindas af bruk och vantro. [II:I, s.93]

Möjligen kände Bremer inte någon dragning i sin ande att visa yttre tecken på kärlek inne i helgedomen, men i naturen, närmare bestämt $\mathrm{i}$ Getsemane, får hon däremot svårt att hålla känslorna i styr. Här är det hon som blir skyldig till att "bindas af bruk" - egentligen skulle hon vilja vara mycket närgången.

Träd intar en särställning i Bremers tänkande och olivträdet är den art som fascinerar henne allra mest, eftersom det är odödligt i den meningen att det växer upp på nytt - med rotskott - även om det huggs ner. Kanske bad Jesus i ångest under just dessa träd? Den inre synen får en särskild konkretion, men Bremer utmålar inte fantasin, utan koncentrerar i stället det emotionella innehållet i en utläggning om träden.

Jag har aldrig sett några träd med så mensklig fysionomi, som dessa urgamla olivträd. Här, i Gethsemane, äro i synnerhet två eller tre, som man icke kan betrakta, utan att besynnerligen gripas. De starka, klufna stammarne, dels vridna, dels fårade och märkta såsom af djupa tankar och tårar; den rika skugga, som sprides under deras mäktiga, utsträckta grenar, fulla af löf och af frukter, (nu bittra men - när de mognat - fulla af ljuflig olja.) O! dessa träd! jag hade velat knäfalla 
vid dem, och omfatta dem med mina armar, trycka mot deras bark mina läppar, mitt hjerta och — -; men flera personer voro i trädgården och — jag skämdes att gifva mina känslor luft. [II:I, s.96]

Bremers förakt för relikdyrkan och för att uppfatta kyssandet av ikoner som gudstjänst hamnar här i ett annat ljus. Endast den sociala kontrollen hindrar henne från att kyssa olivträden. För att landskapet ska bli meningsbärande för Bremer måste hon emellertid omdefiniera hur det producerar mening. Hon utarbetar en kritisk metod.

\section{Landskap: ikon, relik, symbol}

En av fördelarna med Olivberget är, enligt Bremer, att man kan vara helt säker på att platsen är den riktiga, eftersom varken plog eller kritik kan riva ner en så mäktig höjd. Här eller där har trots allt betydelse. Anledningen till att pilgrimsfärder till det Heliga Landet, trots motstånd, blev så populära ligger enligt antropologerna Coleman och Elsner i längtan efter att se och röra. Redan en av Jerusalems första biskopar på 300-talet betonade sinnesutvidgningen: "andra kan enbart höra, men vi ser och rör" [Cyril av Jerusalem, cit. hos Coleman \& Elsner, 1995, s. 84]. Landskapet fungerar, i en ofta upprepad formulering, som ett femte, beröringsbart evangelium. ${ }^{10}$

I en studie av kartor över det Heliga Landet visar Pnina Arad att landskapet för de tidigaste pilgrimerna fick en dubbel funktion som minne och som bevis. De heliga händelserna ansågs ha gjort avtryck i den fysiska omgivningen; landskapet uppfattades som en behållare för gudomlig nåd, marken hade fått eget liv — den hade med andra ord blivit en ikon. Arad betonar att denna föreställning om ett slags ikonisk plats föregriper kulten av ikoniska bilder, som fick genomslag först på 500-talet [Arad, 2012]. En konkurrerande uppfattning vänder sig mot tanken att marken i sig själv skulle vara en behållare för gudomlig nåd, men vidmakthåller att den helgats genom kontakt med det gudomliga. Lock menar att de brittiska protestantiska 1800-talspilgimerna närmar sig denna hållning: strängt taget uppfattas landskapet som en gigantisk, orörlig relik [Lock, 2003, s. 121f]. Ruth och Thomas Hummel formulerar istället denna uppfattning som ett sakrament. I sin jämförelse mellan brittiska protestantiska och ryska ortodoxa 1800-talspilgrimer betonar

${ }^{10}$ Lock lyfter t.ex. fram J.M.P. Otts titel The Fifth Gospel: The Land where Jesus Lived (1893). Lock, s. 121. Se även Queen, II, s. 212. 
de att landskapet betyder något mer än ett minne. För många protestantiska pilgrimer blir Jesus närvarande, levande; det Heliga Landet blir ett slags uppenbarelse, "a channel of grace - a sacrament" [Hummel \& Hummel, 1995, s.26ff]. Bremers utgångspunkt liknar denna hållning, men hon utarbetar sin egen version.

Bremers kritiska metod redovisar i första steget icke-protestantiska pilgrimers förställningar och praktiker vid heliga platser. I nästa steg kritiseras dessa föreställningar och praktiker: teologiskt med utgångspunkt i den protestantiska övertygelsen och historiskt i linje med samtida liberalteologi. ${ }^{11}$ Bremers vistelse i Palestina ägde rum samtidigt som de arkeologiska utgrävningarna runt om i landet tagit fart och tycktes bekräfta Bibelns sanning. ${ }^{12}$ I likhet med andra liberalteologer såg Bremer ingen motsättning mellan tro och vetenskap: "Tron är vetandets hjerta. Vetandet är trons kropp och sköld.” [Bremer, 1842, s. 54f.] Tron är det innersta, vissheten, som stöds av logiska resonemang, även om den yttersta insikten inte är ett resultat av en logisk slutledning. Denna inre visshet uppfattar Bremer som en "Paradisbild" och den tvingar henne att ifrågasätta både katolska och protestantiska trossatser [Bremer 1860. I:II, s. 266]: “Tviflar jag på min förmåga att inse sanningen, så måste jag tvifla på allt hvad jag ser. Men jag kan icke det och ändock lefva.” [I:II, s.269]

Alla trosföreställningar måste emellertid fortfarande kunna stödjas av logik. Med hjälp av historisk och arkeologisk kunskap samt egen empirisk kännedom om platsen diskuterar därför Bremer var Golgata, via dolorosa eller Lasarus grav rimligen kan ha varit belägna, men drar slutsatsen att en exakt lokalisering inte går att fastställa. I sista steget omdefinierar hon platsen och anvisar ett annat förhållningssätt. När det gäller Heliga gravens kyrka erinrar Bremer om människors naturliga behov av att vårda de älskades minne genom att vårda gravar, och "rummet, der min herre och mästare legat, kunde ej vara mig likgiltigt" [II:I,

${ }^{11}$ I Bremers samtid rasade en hätsk debatt om teologen David Friedrich Strauss bok Das Leben Jesu kritisch bearbeitet (1835), som hävdade att Jesus visserligen varit en historisk person som gott kunde tjäna som moraliskt föredöme, men att han ingalunda var Guds son samt att Bibelns mirakelberättelser är myt. Bremer deltog i debatten och intog en mellanställning, som gjorde henne impopulär i båda lägren: Bibeln bör utsättas för vetenskaplig, kritisk granskning, men tron på att Jesus är Guds son är oundgänglig. Bremer, 1842. Se även Bremer 1861 II:II, s. 78ff. För en diskussion om Bremers förhållande till liberalteologin se Hammar, 2001.

${ }^{12}$ Ang. Edward Robinsons arkeologiska utgrävningar på 1830- och 1850-talen, se Queen, II, s.212f. 
s. 89], om än det exakta stället var "här eller litet längre bort" [II:I, s. 94]. Platsen blir varken en ikon eller relik, utan ger förankring för minnespraktiker. Ofta är hon dock betydligt mer specifik i sin omtolkning.

Den historiska via dolorosa befinner sig långt under dagens marknivå och Bremer fäster ingen betydelse vid huruvida stationerna markerar historiskt riktiga ställen eller ej. Meningsproduktionen är trots det fortfarande knuten till plats: "Det dramatiska intresset för mig, ligger i karakteren af denna långa trånga väg med sina mörka smärtostationer, så olika med Salomo's tempelgårdar, och att denna väg fritt valdes af den, som en dag stod som lärare i detta tempel [...].” [II:I, s. 139] På liknande sätt besöker hon Lasarus grav, rapporterar att den enligt arkeologerna förmodligen inte är äkta, slår fast att detta saknar betydelse och omdefinierar landskapet: "bland dessa klippor, i denna omgifning tilldrog sig ett uppträde, som uppenbarade Jesu hjerta och Jesu kraft" [II:I, s. 108]. Om Lasarus verkligen uppväcktes från döden, menar Bremer är av underordnad betydelse - den materiella verkligheten blir inte meningsskapande genom det eventuella underverket, utan därför att Jesus grät och därmed visade Guds medkänsla med mänskligt lidande: "För mig hafva Jesu tårar helgat Bethaniens jord.” [II:I, s. 109] Platserna förankrar minnet genom att den trånga via dolorosa blir en konkret bild av Jesu självvalda lidande, medan Betanias klippor påminner om Jesu medlidande. Bremer uppfattar själv denna tolkningspraktik som symbolisk.

Symbolen får också sista ordet när Bremer kommer till det som idag kallas för Trädgårdsgraven, eller det som "de evangeliska och tänkande männen här anse vara det verkliga, historiska Golgatha” [II:II, s. 74], som hon uttrycker saken. Det som avgör att hon accepterar platsen som den historiskt korrekta är inte arkeologiska fynd, utan att i läget "ligger en rörande symbolik" [II:II, s.74]: den ligger avskild från Jerusalem men mitt emot Olivberget. Bremer antar att Jesu ljusaste minnen är kopplade till Olivberget, där han vandrat med lärjungarna och umgåtts med syskonen i Betania, och att han därför i det yttersta lidandet hade utsikt över livets skönhet. Detta är platsens mening och därför är stället det rätta. Topografins symbolik blir garant för sanning - både för historisk sanning och själens sanning.

\section{Allegorisk geografi}

När Bremer lämnar Palestina sammanfattar hon de sista dagarnas rundresa i Galileen med glädjen över att 
nu äga dessa orter i min själ i så klara och bestämda drag, som någon ort från mitt hemland. Förr voro de skuggbilder, nu hafva de blifvit ljusbilder för mitt sinne. [II:II, s. 163]

Platserna har blivit konkret verklighet och den stora vinsten ligger i att Bibelns orter har blivit ett hemland, inte bara för själen, utan också för sinneserfarenheten. Utbytet mellan själens bild och verkligheten kan jämföras med hennes allra första iakttagelse av Jerusalem på avstånd. Den syn som hänfört så många upplevde Bremer som nedslående: en grå stad, en skugga bland skuggorna” [II:I, s. 86]. Guds stad i själen är det hem alla människor längtar till och för att understryka detta citerar Bremer därpå ett rejält stycke om Uppenbarelsebokens skinande stad, men avslutar med att "detta Jerusalem är långt, långt ifrån det jordiska" [I:II, s. 78]. I slutet av resan har emellertid polerna för ljus och mörker bytt plats. I den summerande anmärkningen är det tvärtom själens bilder, skapade av texten, som kallas "skuggbilder", medan den fysiska platsen har framkallat "ljusbilder". I Bremers framställning är det sinnligt tillgängliga ett självändamål.

En tradition gör gällande att Jesu sista fotspår på jorden finns bevarat i klippan där han steg upp till himmelen - en befängd tanke, enligt Bremer, men fotspårets geografiska läge har däremot betydelse. Det passar enligt henne mycket bra för missionsbefallningen, eftersom "det ligger emellan öknen och den odlade verlden, emellan Döda hafvet och Medelhafvet - i medelpunkten snart sagdt af alla jordens verldsdelar" [II:I, s.99]. Innebörden i missionsbefallningen, att sprida evangelium, är avläsbar och fysiskt tillgänglig i topografin. Bremer anser att hon därmed uppfattar landskapet symboliskt, men om man ska analysera hur verkligheten producerar mening i hennes teologisk-historiska teori måste man konstatera att hon utgår från bibeltexten som en sanning och omdefinierar landskapet för att uttrycka denna sanning. Bremers tolkningspraktik är allegorisk snarare än symbolisk: texten föregår och gestaltas i verkligheten. ${ }^{13}$

Strängt taget pågår samma allegoriserande praktik i Bremers omdefiniering av via dolorosa och Getsemane. Det var, som sagt, "karakteren af denna långa trånga väg med sina mörka smärtostationer” (II:I,

${ }^{13}$ Forskningen om förhållandet mellan allegori och symbol är mycket omfattande och definitionerna har förändrats avsevärt över tid. För en diskussion om symbol och allegori se t.ex. de Man, 1983. Ang. allegori se även Quilligan, 1979. 
s. 139) och möjligheten att läsa in en gestaltning av det självvalda lidandets väg i gatunätet, som gjorde via dolorosa meningsfull. Getsemanes olivträd omdefinieras i en långtgående antropomorfisering, som dessutom utvecklar en allegori över inkarnationen. Olivträden är en predikan över Guds död på korset så god som någon: varje del av beskrivningen har en motsvarighet i Jesu lidande och död. Träden, korsets material, är "fårade och märkta såsom af djupa tankar och tårar" och får en "mensklig fysionomi” (II:I, s. 96) som uttrycker starkt lidande, men som ger hugsvalelse för den som sluter sig till dem, och det bittra ska vändas i ett underbart livsmedel (olja). Allegorin gör trädet Kristuslikt, till en kropp som väcker vördnad och kärlek. Att kyssa olivträd är hos Bremer en fantasi om att kyssa den inkarnerade guden.

Vid ett tillfälle tillbringar Bremer en natt i ett torn högst upp på Olivberget bredvid moskéns minaret, beskyddad av shejken och hans hustru. Hon önskar se soluppgången. Den uppgående solens strålar låter det bibliska landskapets olika landmärken framträda och Bremer följer i fantasin solstrålarna vidare "till Europa och Afrikas länder och bortom hafvet till den fjerran verldsdel, der alla verldsdelars folk och frukter komma tillsammans, der kanske ännu ljusets ädlaste frukter skola mogna” (II:I, s. 171). Solens strålar förbinder Palestina, Bibelns land, med Amerika, framtidens land. Geografin är en gestaltning av världshistorien. Denna allegoriska geografi är ingen ny tanke för Bremer den genomsyrar både hennes egen och flera andra samtida reseskildringar från Amerika. Amerikas geografiska läge och klimatologiska förutsättningar bevisar enligt dem att försynen avsett landet som en samlingsplats för jordens folk och framtidens förlovade land [Bohlin, 2013]. I försynens plan har givetvis Palestina en nyckelroll.

Bremer lutar sig mot en erkänd auktoritet, geografen Carl Ritter (1779-1859), och slår fast: "landets läge och geografi höra med i Försynens verldsplan" genom "dess afskildhet medelst öknen och hafvet" samtidigt som det står i förbindelse med "de rundtom liggande, stora kultur-folken" och "med de trenne verldsdelarne Asien, Afrika och Europa” [Bremer, II:I, s.217]. Bremer utlägger därpå betydelsen av detta läge - kombinationen av enslighet, som främjar koncentrationen på en enda Gud, och kontakt, som gör budskapet tillgängligt. Konsekvensen blir att

när Palestinas rike upplöstes och Jerusalem förstördes, så måste åter dess folk, med eller mot sin vilja, gå ut ibland alla folk och vittna 
om den uppenbarelse, som främst bland alla blef Israel till del. [II:I, s. 218]

Med eller mot sin vilja - historiens krafter som ingen människa kan motstå är nedlagda redan i landskapets utformning. Det är inte bara Palestina som är ett heligt landskap; Guds plan är inskriven i hela jordens geografi. Mississippi är lika helig som Jordan — även om Jordan är mer minnesrik och inbjuder till fler allegoriska utläggningar [II:I, s. 198f.].

Den envisa frågan kvarstår dock fortfarande: varför måste Bremer resa till Palestina? Det enkla svaret är: hon vallfärdade till det Heliga Landet för att se solen gå upp över Olivberget. Det omvandlar den abstrakta teorin till sinneserfarenhet. Den teologisk-historiska rörelsen materialiseras i upplevelsen av solstrålarnas vandring över Palestinas landskap. Denna sinnliga upplevelse inger visshet, den visshet som inte låter sig resoneras fram. Estetik betyder ursprungligen "sinnlig varseblivning" och det är just själva sinneserfarenheten som ställs i centrum i hur platsen skapar mening i Bremers verk. Sinnligheten ger ljusbilderna, den fysiska upplevelsen av atmosfären på via dolorosa - lång, trång, mörk — och den ljuvliga utsikten över Olivberget från Trädgårdsgraven som låter sig tolkas övertygar Bremer om platsens sanning. I resonemanget om grunden för sanningsanspråken, som jag diskuterade ovan, betonar Bremer behovet av inre harmoni: "Jag måste söka öfverensstämmelse med mitt förnuft, mitt hjerta, mitt samvete [...]. Stadna i motsägelse är att stadna i helvetet.” [I:II, s.269f.] Sinnesintrycket ger denna inre harmoni som låter förnuftets, hjärtats och samvetets sanning sammanfalla. Den estetiska erfarenheten ger visshet.

Landskapet, omdefinierad till allegorisk geografi producerar mening i Bremers teologisk-historiska teori: landskapet fungerar som en utläggning av evangelium. Hon avvisar tron på ikoner och reliker, men meningsproduktionen är fortfarande kopplad till plats, eftersom visshet uppnås genom det estetiska sinnesintrycket. Det låter skuggbilder bli sinnliga ljusbilder och det öppnar för möjligheten att kyssa olivträd.

\section{REFERENCES}

Arad P. Mapping Divinity: Holy Landscape in Maps of the Holy Land. Jerusalem as Narrative Space. Erzählraum Jerusalem. Eds. A. Hoffmann, G. Wolf. Leiden, Boston, Brill, 2012, pp. 263-276.

Badone E., Roseman S.R. (ed.). Intersecting Journeys: The Anthropology of Pilgrimage and Tourism. Urbana, University of Illinois Press, 2004. 199 p. 
Bohlin A. Fredrika Bremer's Concept of the Nation During her American Journey. Ideas in History, 2013, vol. 7, no. 1-2, pp. 43-70.

Bohlin T. Fredrika Bremer och kyrkoläran. Årsbok förkristen humanism, 1966, pp. 70-85.

Bowman G. Christian ideology and the image of a holy land: the place of Jerusalem pilgrimage in the various Christianities. Contesting the Sacred. The Anthropology of Christian Pilgrimage. Eds. J. Eade, M. J. Sallnow. London, New York, Routledge Publ., 1991, pp. 98-121.

Bremer F. Morgon-väckter. Några ord $i$ anledning af "Strauss och evangelierne"; tros-bekännelse. Stockholm, L. J. Hjerta Publ., 1842. $82 \mathrm{s.}$

Bremer F. Lifvet i gamla verlden. Dagboks-anteckningar under resor i Söder-och Österland, del I:II, II:I och II:II. Stockholm, Upsala, Adolf Bonnier, 18601861. 412 s., 239 s., 299 s.

Brodd S.-E. 'Jag är mer katolsk än så. Ett bidrag till frågan om Fredrika Bremers kyrkouppfattning. Den kommunikativa kyrkan. Festskrift till Bernice Sundkvist på 60-årsdagen. Eds. B. Sarelin, M. Lindfelt. Skellefteå, Artos, Norma bokförlag Publ., 2016, pp. 197-228.

Burman L., C. Kommentarer och ordförklaringar. Bremer F. Livet i gamla världen. Palestina. Svenska Akademien, Stockholm, Atlantis Publ., 1995, pp. 405-429.

Coleman S., Eade J. Introduction: Reframing pilgrimage. Reframing Pilgrimage. Cultures in Motion. London, New York, Routledge, 2004, pp. 1-25.

Coleman S., Elsner J. Pilgrimage Past and Present. Sacred Travel and Sacred Space in the World Religions. London, British Museum Press, 1995. 240 p.

Coleman S., Elsner J. Pilgrim Voices: Authoring Christian Pilgrimage. Pilgrim Voices. Narrative and Authorship in Christian Pilgrimage. Esd. S.Coleman, J. Elsner. New York, Oxford, Berghahn Books, 2003, pp. 1-16.

Craig L. A. Wandering Women and Holy Matrons. Women as Pilgrims in the Later Middle Ages. Leiden, Boston, Brill, 2009. 308 p.

Edwards P. Pilgrimage and Literary Tradition. Cambridge, Cambridge University Press, 2005. $218 \mathrm{p}$.

Gunner G. Fertile Soil and Swampy Ground: Through the Eyes of Travellers. Patterns of the Past, Prospects for the Future. The Christian Heritage in the Holy Land. Eds. T. Hummel, K. Hintlian, U. Carmesund. London, Melisende Publ., 1999, pp. 273-282.

Hammar I. Fredrika Bremers Morgon-väckter. En provokation mot rådande genusordning. Mig törstar! Studier i Fredrika Bremers spår. Eds. Å. Arping, B. Ahlmo-Nilsson. Hedemora, Gidlunds Publ., 2001, pp. 141-164.

Harper L. M. Solitary Travelers. Nineteenth-Century Women's Travel Narratives and the Scientific Vocation. London, Cranbury, Mississauga, Associated University Presses, 2001. 277 p.

Hummel R., T. Patterns of the Sacred. English Protestant and Russian Orthodox Pilgrims of the Nineteenth Century. London, Scorpion Cavendish Publ., 1995. $76 \mathrm{p}$. 
Lock C. Bowing Down to Wood and Stone: One Way to be a Pilgrim. Pilgrim Voices. Narrative and Authorship in Christian Pilgrimage. Eds. S. Coleman, J. Elsner. New York, Oxford, Berghahn Books, 2003, pp.110-132.

de Man P. The Rhetoric of Temporality [1969]. Blindness and Insight: Essays in the Rhetoric of Contemporary Criticism. London, Routledge Publ., 1983, pp. 187228.

Margry P. J. Secular Pilgrimage: A Contradiction in Terms? Shrines and Pilgrimage in the Modern World. New Itineraries into the Sacred. Ed. by P.J.Margry. Amsterdam, Amsterdam University Press, 2008, pp. 13-46.

Moore H. The Pilgrimage of Passion in Sidney's Arcadia. Pilgrim Voices. Narrative and Authorship in Christian Pilgrimage. Eds. Coleman, Elsner. New York, Oxford, Berghahn Books, 2003, pp. 61-81.

Pratt M. L. Imperial Eyes. Travel Writing and Transculturation. London, New York, Routledge Publ., 1992. 257 p.

Schramm K. Coming home to the Motherland: Pilgrimage tourism in Ghana. Reframing Pilgrimage. Cultures in Motion. Eds. S. Coleman, J.Eade. London, New York, Routledge Publ., 2004, pp. 133-149.

Queen II E. L. Ambiguous Pilgrims: American Protestant Travelers to Ottoman Palestine, 1867-1914. Pilgrims \& Travelers to the Holy Land. Eds. B. F. Le Beau, M. Mor. Omaha, New York, Creighton University Press, 1996, pp. 209-228.

Quilligan M. The Language of Allegory: Defining the Genre. Ithaca,Cornell University Press, 1979. 305 p.

Thompson C. Travel Writing. New York, Routledge Publ., 2011. 229 p.

Williams W. 'A Mirrour of Mis-Haps,/ A Mappe of Miserie.' Dangers, strangers, and friends in Renaissance pilgrimage. The "Book" of Travels. Genre, Ethnology, and Pilgrimage, 1250-1700. Ed. by P. Brummett. Leiden, Boston, Brill Publ., 2009, pp. 205-239.

\section{Анна Болин \\ кандидат филологических наук, научный сотрудник кафедры этнологии, истории религии и гендерных исследований Стокгольмского университета E-mail: anna.bohlin@gender.su.se}

\section{Anna Bohlin}

$\mathrm{PhD}$, Researcher at the Department of Ethnology, History of Religions and Gender Studies, Stockholm University

SE-106 91 Stockholm, Sweden

E-mail: anna.bohlin@gender.su.se 